\title{
A novel classification for local recurrence after surgical removal of renal cell cancer
}

\author{
Takeshi Yuasa \\ Department of Urology, Cancer Institute Hospital, Japanese Foundation for Cancer Research, Ariake, Tokyo, Japan \\ Correspondence to: Takeshi Yuasa, MD, PhD. 3-8-31 Ariake, Tokyo 135-8550, Japan. Email: takeshi.yuasa@jfcr.or.jp. \\ Provenance and Peer Review: This article was commissioned and reviewed by the Section Editor Dr. Xiao Li (Department of Urology, Jiangsu Cancer \\ Hospital, Jiangsu Institute of Cancer Research, Nanjing Medical University Affiliated Cancer Hospital, Nanjing, China). \\ Comment on: Lee Z, Jegede OA, Haas NB, et al. Local Recurrence Following Resection of Intermediate-High Risk Nonmetastatic Renal Cell \\ Carcinoma: An Anatomical Classification and Analysis of the ASSURE (ECOG-ACRIN E2805) Adjuvant Trial. J Urol 2020;203:684-9.
}

Submitted Mar 06, 2020. Accepted for publication Mar 18, 2020.

doi: 10.21037/atm.2020.03.199

View this article at: http://dx.doi.org/10.21037/atm.2020.03.199

Surgery is the most effective treatment for localized renal cell cancer (RCC) and, as such, is the standard of care (1). For a long time, radical nephrectomy was the gold standard for localized RCC (1). Nowadays, however, partial nephrectomy appears to be the first treatment choice when technically feasible without worsening the oncological outcome $(1,2)$. Conversely, radical nephrectomy is often selected for local advanced RCC $(1,2)$. Twenty to forty percent of patients with these localized RCC will have recurrence, mainly as pulmonary, osseous, and/or liver metastasis as distant metastasis $(3,4)$. Among these recurred patients, local recurrence is infrequent when compared to these systemic metastasis $(4,5)$. These patients with local recurrence, however, must be considered at high risk of developing distant metastatic disease. Currently, there is no standardized definition or classification for local recurrence after surgical removal of RCC.

The ASSURE (ECOG-ACRIN E2805, Adjuvant Sorafenib or Sunitinib for Unfavorable REnal carcinoma) is the phase III, multi-center, international placebo-controlled trial that accessed the efficacy of adjuvant tyrosine kinase inhibitors (TKI) in patients with high-risk RCC after surgical removal of the primary tumor (6). Unfortunately, the ASSURE trial could not demonstrate an improvement in either disease-free or overall survival (OS) rates with adjuvant TKI therapy (6). The prospective cohorts are, however, sometimes re-used to examine other important clinical questions. In a recent article in Fournal of Urology, Lee et al. described a novel classification system for local recurrence after surgery for RCC using the ASSURE trial cohort (7). Trial data was queried for patients with surgically removed non-metastatic RCC with local recurrence. They defined local recurrence as any intra-abdominal recurrence without extra-abdominal recurrence (i.e., lung, brain, and bone) and classified them into the following four categories: Type I: single recurrence in a remnant kidney or ipsilateral renal fossa; Type II: single recurrence in ipsilateral vasculature, ipsilateral adrenal gland, or a lymph node; Type III: single recurrence in other intra-abdominal soft tissues or organs; and Type IV: any combination of Types I-III, or multiple recurrences within a single type (7). Compared to a solitary local recurrence at a single anatomic subdivision (Types I-III), local recurrence involving multiple sites and/ or subdivisions (Type IV) was associated with worse 5 -year cancer-specific survival (CSS: $65.1-72.0 \%$ vs. $40.2 \%$ ) and OS $(60.2-66.0 \%$ vs. $35.0 \%)$, and shorter time to local recurrence (2-year local recurrence-free rates: $39.2-51.7 \%$ vs. $26.0 \%$ ) (7). In addition, when local recurrence was limited to a solitary lesion, there was no difference in CSS and OS, regardless of its intra-abdominal anatomic subdivision (Types I-III) (7).

The authors presented this classification as having several characteristics (7). It distinguishes recurrence in the remnant kidney or ipsilateral renal fossa (Type I) from that in the ipsilateral vasculature, adrenal gland, or lymph node (Type II) (7). It also includes intra-abdominal soft tissue or organ (Type III) recurrence, although this class is often considered to be systemic metastasis (7). In addition, this classification 
includes another category of multiple recurrences or recurrence at multiple sites as Type IV (7). A standardized definition and classification of local recurrence after surgical removal of RCC is of great importance for clinical practice. When this classification is accepted worldwide, clinical data will be accumulated for the respective local recurrence types. This would enable validation of this classification and discussion of the treatment strategy in the respective types of patients with local recurrence. Surgical removal still plays an important role in this category, especially in solitary recurrence $(8,9)$. Also, recently advanced systemic therapies, including the TKI, the inhibitors of mechanistic target of rapamycin (mTOR), and the immune checkpoint inhibitors, function as effective therapeutic tools $(9,10)$. We expect to be able to establish the treatment strategy in this category, which will benefit RCC patients with local recurrence.

\section{Acknowledgments}

Funding: This work was partly supported by the Smoking Research Foundation and JSPS KAKENHI Grant Number 16K11035 (TY).

\section{Footnote}

Conflicts of Interest: The author has completed the ICMJE uniform disclosure form (available at http://dx.doi. org/10.21037/atm.2020.03.199). The author has no conflicts of interest to declare.

Ethical Statement: The author is accountable for all aspects of the work in ensuring that questions related to the accuracy or integrity of any part of the work are appropriately investigated and resolved.

Open Access Statement: This is an Open Access article distributed in accordance with the Creative Commons Attribution-NonCommercial-NoDerivs 4.0 International License (CC BY-NC-ND 4.0), which permits the noncommercial replication and distribution of the article with the strict proviso that no changes or edits are made and the original work is properly cited (including links to both the formal publication through the relevant DOI and the license). See: https://creativecommons.org/licenses/by-nc-nd/4.0/.

\section{References}

1. EAU guideline. Renal Cell Carcinoma. Available online: https://uroweb.org/guideline/renal-cell-carcinoma/

2 Veccia A, Antonelli A, Uzzo RG, et al. Predictive Value of Nephrometry Scores in Nephron-sparing Surgery: A Systematic Review and Meta-analysis. Eur Urol Focus 2020;6:490-504.

3 Psutka SP, Master VA. Role of metastasis-directed treatment in kidney cancer. Cancer 2018;124:3641-55.

4 Psutka SP, Heidenreich M, Boorjian SA, et al. Renal fossa recurrence after nephrectomy for renal cell carcinoma: prognostic features and oncological outcomes. BJU Int 2017;119:116-27.

5 Romeo A, Garcia Marchiñena P, Jurado AM, et al. Renal fossa recurrence after radical nephrectomy: Current management, and oncological outcomes. Urol Oncol 2020;38:42.e7-42.e12.

6 Haas NB, Manola J, Uzzo RG, et al. Adjuvant sunitinib or sorafenib for high-risk, non-metastatic renal-cell carcinoma (ECOG-ACRIN E2805): a double-blind, placebo-controlled, randomised, phase 3 trial. Lancet 2016;387:2008-16.

7 Lee Z, Jegede OA, Haas NB, et al. Local Recurrence Following Resection of Intermediate-High Risk Nonmetastatic Renal Cell Carcinoma: An Anatomical Classification and Analysis of the ASSURE (ECOGACRIN E2805) Adjuvant Trial. J Urol 2020;203:684-9.

8 Kriegmair MC, Bertolo R, Karakiewicz PI, et al. Systematic Review of the Management of Local Kidney Cancer Relapse. Eur Urol Oncol 2018;1:512-23.

9 Bamias A, Escudier B, Sternberg CN, et al. Current Clinical Practice Guidelines for the Treatment of Renal Cell Carcinoma: A Systematic Review and Critical Evaluation. Oncologist 2017;22:667-79.

10 Yuasa T, Masuda H, Yamamoto S, et al. Biomarkers to predict prognosis and response to checkpoint inhibitors. Int J Clin Oncol 2017;22:629-34.
Cite this article as: Yuasa T. A novel classification for local recurrence after surgical removal of renal cell cancer. Ann Transl Med 2020;8(15):970. doi: 10.21037/atm.2020.03.199 